Technical Note

\title{
A New MODIS C6 Dark Target and Deep Blue Merged Aerosol Product on a 3 km Spatial Grid
}

\author{
Muhammad Bilal $^{1}$ (1) , Zhongfeng Qiu $^{1, *}{ }^{(1)}$, James R. Campbell ${ }^{2}$ (D), Scott N. Spak ${ }^{3}$ (), \\ Xiaojing Shen ${ }^{4}$ and Majid Nazeer ${ }^{5}$ (D) \\ 1 School of Marine Sciences, Nanjing University of Information Science \& Technology, Nanjing 210044, China; \\ muhammad.bilal@connect.polyu.hk \\ 2 Naval Research Laboratory, Monterey, CA 93943, USA; james.campbell@nrlmry.navy.mil \\ 3 School of Urban \& Regional Planning, University of Iowa, Iowa City, IA 52242, USA; scott-spak@uiowa.edu \\ 4 School of Atmospheric Sciences, Nanjing University of Information Science \& Technology, Nanjing 210044, \\ China; ShenXJ@nuist.edu.cn \\ 5 Earth and Atmospheric Remote Sensing Lab (EARL), Department of Meteorology, COMSATS Institute of \\ Information Technology, Islamabad 45550, Pakistan; majid.nazeer@comsats.edu.pk \\ * Correspondence: zhongfeng.qiu@nuist.edu.cn; Tel.: +86-025-5869-5696
}

Received: 16 February 2018; Accepted: 13 March 2018; Published: 15 March 2018

\begin{abstract}
In Moderate Resolution Imaging Spectroradiometer (MODIS) Collection (C6) aerosol products, the Dark Target (DT) and Deep Blue (DB) algorithms provide aerosol optical depth (AOD) observations at $3 \mathrm{~km}\left(\mathrm{DT}_{3 \mathrm{~K}}\right)$ and $10 \mathrm{~km}\left(\mathrm{DT}_{10 \mathrm{~K}}\right)$, and at $10 \mathrm{~km}$ resolution $\left(\mathrm{DB}_{10 \mathrm{~K}}\right)$, respectively. In this study, the $\mathrm{DB}_{10 \mathrm{~K}}$ is resampled to $3 \mathrm{~km}$ grid $\left(\mathrm{DB}_{3 \mathrm{~K}}\right)$ using the nearest neighbor interpolation technique and merged with $\mathrm{DT}_{3 \mathrm{~K}}$ to generate a new DT and DB merged aerosol product (DTB $\mathrm{DK}_{3 \mathrm{~K}}$ ) on a $3 \mathrm{~km}$ grid using Simplified Merge Scheme (SMS). The goal is to supplement $\mathrm{DB}_{10 \mathrm{~K}}$ with high-resolution information over dense vegetation regions where $\mathrm{DT}_{3 \mathrm{~K}}$ is susceptible to error. SMS is defined as "an average of the $\mathrm{DT}_{3 \mathrm{~K}}$ and $\mathrm{DB}_{3 \mathrm{~K}} \mathrm{AOD}$ retrievals or the available one with the highest quality flag". $T_{\text {The }} \mathrm{DT}_{3 \mathrm{~K}}$ and $\mathrm{DTB}_{3 \mathrm{~K}}$ AOD retrievals are validated from 2008 to 2012 against cloud-screened and quality-assured AOD from 19 AERONET sites located in Europe. Results show that the percentage of $\mathrm{DTB}_{3 \mathrm{~K}}$ retrievals within the expected error $(\mathrm{EE}= \pm(0.05+20 \%))$ and data counts are increased by $40 \%$ and $11 \%$, respectively, and the root mean square error and the mean bias are decreased by $26 \%$ and $54 \%$, respectively, compared to the $\mathrm{DT}_{3 \mathrm{~K}}$ retrievals. These results suggest that the $\mathrm{DTB}_{3 \mathrm{~K}}$ product is a robust improvement over $\mathrm{DT}_{3 \mathrm{~K}}$ alone, and can be used operationally for air quality and climate-related studies as a high-resolution supplement to the current MODIS product suite.
\end{abstract}

Keywords: AERONET; MODIS C6; AOD; DT AOD; DB AOD; Merged AOD

\section{Introduction}

Atmospheric aerosols, small tiny particles suspended in the atmosphere, are emitted from multiple sources by anthropogenic and natural activities, including smoke, volcanic ash, dust particles, biomass burning, and particular matters. These particles are associated with uncertainties in the Earth's radiation budget and climatic system [1], degradation of atmospheric visibility [2,3], and public health diseases and mortality [4-9]. A ground-based sunphotometer network [10-12] has been established for regular monitoring of aerosol particles by providing high temporal and spectral information, but this network is spatially limited, particularly over open oceans. Satellite remote sensing overcomes this limitation and provides a spatial distribution of aerosol optical properties such as aerosol optical depth (AOD) on the global scale. AOD can be obtained from geostationary and polar satellites at different spatiotemporal resolutions over both land and ocean surfaces [13-26]. 
The Moderate Resolution Imaging Spectroradiometer (MODIS) sensors onboard the Terra and Aqua satellites provide geophysical observations at 36 channels ranging from 0.4 to $14.4 \mu \mathrm{m}$ with a temporal resolution of 1-2 days and spatial resolution of $250 \mathrm{~m}, 500 \mathrm{~m}$, and $1000 \mathrm{~m}$. In the MODIS Collection 5.1 (C5.1) level-2 operational aerosol product, daily AOD observations at $10 \mathrm{~km}$ resolution are available over dark surfaces from the Dark Target $\left(\mathrm{DT}_{10 \mathrm{~K}}\right)$ land algorithm $[13,27,28]$, over ocean surfaces from the DT ocean algorithm $[13,29]$, and over bright surfaces from the Deep Blue $\left(\mathrm{DB}_{10 \mathrm{~K}}\right)$ algorithm [16,30,31]. These AOD observations are unable to resolve many local-level aerosol features due to their inherently coarse resolution. Therefore, the DT AOD product at $3 \mathrm{~km}$ resolution $\left(\mathrm{DT}_{3 \mathrm{~K}}\right)$ is introduced in the Collection 6 (C6) operational AOD product [32], as a supplement to the $\mathrm{DT}_{10 \mathrm{~K}}$ [13] and $\mathrm{DB}_{10 \mathrm{~K}}[16] \mathrm{AOD}$ products. $\mathrm{DT}_{3 \mathrm{~K}}$ is generated using the same inversion method as used in $\mathrm{DT}_{10 \mathrm{~K}}$, the only difference being in the selection of the dark target pixels [32].

For the development of the $\mathrm{DT}_{3 \mathrm{~K}}$ algorithm over land [13,32], dark target pixels are selected using the top-of-atmosphere (TOA) reflectance between 0.01 and 0.25 in the $2.11 \mu \mathrm{m}$ channel. Then, selected pixels are organized into retrieval windows of 6 pixels $\times 6$ pixels (36 pixels) for subsequent aerosol retrievals. Pixels in the retrieval windows are masked for clouds, snow /ice, and other bright surfaces, and separated by land and water pixels. From the remaining pixels, the darkest $20 \%$ and brightest $50 \%$ in the retrieval window are discarded using the $0.66 \mu \mathrm{m}$ channel with, at most, 11 pixels in the retrieval window being required to perform aerosol retrievals. In this process, pixels retained at $3 \mathrm{~km}$ resolution might be discarded at $10 \mathrm{~km}$ resolution. With fewer pixels contributing to the $\mathrm{DT}_{3 \mathrm{~K}}$ retrieval, it yields a noisier product than the $\mathrm{DT}_{10 \mathrm{~K}}$ retrieval $[13,32]$. The $\mathrm{DT}_{3 \mathrm{~K}}$ product has been validated over several regions and exhibits larger errors than the $\mathrm{DT}_{10 \mathrm{~K}}$ product due to underestimation of the estimated surface reflectance and incorrect use of the available "look-up" aerosol models [13,32-36]. The expected error (EE) of the $\mathrm{DT}_{3 \mathrm{~K}}$ over land is $\pm(0.05+20 \%)[13,32]$ which represents a one standard deviation confidence interval around the retrieved AOD (i.e., about $68 \%$ of points should fall within \pm EE from the true AOD).

Initially, the MODIS DB algorithm was developed to retrieve AOD over bright surfaces [30,31]. In C6, the Enhanced DB algorithm is used to retrieve AOD over both bright as well as dark surfaces $[16,37,38]$. In developing the DB algorithm, pixels are masked for clouds and snow/ice surfaces, and surface reflectance is estimated for the remaining pixels at $0.412,0.47$, and $0.65 \mu \mathrm{m}$. Thus, AOD is retrieved at $1 \mathrm{~km}$ resolution by finding the best match between satellite TOA reflectance and pre-calculated TOA reflectance stored in a look-up-table (LUT), and then all available pixels are aggregated at $10 \mathrm{~km}$ resolution. The $\mathrm{DB}_{10 \mathrm{~K}} \mathrm{AOD}$ product has been validated in previous studies, which have reported better relative retrieval accuracy than the $\mathrm{DT}_{10 \mathrm{~K}}$ AOD product [35,38-40] with some exceptions [41]. EE for Deep Blue is dependent on the viewing geometry, but is approximately $0.03+20 \%$ on average (i.e., the algorithms have different error characteristics).

MODIS-retrieved AOD $[13,16,42-46]$ is the most frequently used parameter for mapping and estimation of fine particulate matter $\left(\mathrm{PM}_{2.5}\right)$ from local to global scales. The error in MODIS AOD may cause under-/over-estimation in $\mathrm{PM}_{2.5}$ concentrations. Therefore, quality assessment of MODIS AOD is crucial for local and global air quality applications. Studies have performed the quality assessment of the MODIS AOD [35,36,41,42,47-50] and used it in statistical modeling based on the empirical linear regression, land use regression model, and Geo-graphically Weighted Regression (GWR) model for estimation of $\mathrm{PM}_{2.5}$ concentrations at regional and global scales [14,51-64]. These studies found that an accurate estimation of the $\mathrm{PM}_{2.5}$ concentration depends on the quality of the satellite-retrieved AOD observations. Therefore, accurate and robust satellite retrieved AOD retrievals are much needed for solving environmental and air pollution problems.

Previous studies $[33,34,36,40]$ have reported large uncertainty in the $\mathrm{DT}_{3 \mathrm{~K}}$ AOD product at local-to-regional scales. For example, Nichol and Bilal [36] validated the $\mathrm{DT}_{3 \mathrm{~K}} \mathrm{AOD}$ retrievals over 16 AERONET sites in Asia corresponding with urban and vegetated land surfaces, and they found larger errors and overestimation in $\mathrm{DT}_{3 \mathrm{~K}}$. In addition, the DT and DB algorithms have different AOD spatial coverages over land due to differences in pixels selection criteria and their thresholds, 
the surface reflectance calculation method, and cloud mask. Therefore, a new product at higher resolution with low errors and more spatial coverage is preferable to understanding aerosol behavior at something approaching the level of an urban city center.

The main objective of this study is to describe and evaluate a new DT and DB-merged (DTB $3 K$ ) AOD product on a $3 \mathrm{~km}$ grid to improve the quality of AOD retrievals and spatial coverage over vegetated and non-vegetated land surfaces (i.e., to retrieve $\mathrm{AOD}$ for those regions where the $\mathrm{DT}_{3 \mathrm{~K}}$ does not retrieve $\mathrm{AOD}$ due to pixels selection criteria and cloud mask [13], and where $\mathrm{DB}_{10 \mathrm{~K}}$ does not retrieve AOD due to errors in cloud mask that lead to removal of cloud free pixels [16,37]). This study validates $\mathrm{DT}_{3 \mathrm{~K}}$ and $\mathrm{DTB}_{3 \mathrm{~K}}$ AOD products over European AERONET sites located over vegetated surfaces, as the AOD product at $3 \mathrm{~km}$ resolution is only available for the DT algorithm which is supposed to retrieve AOD accurately over vegetated surfaces. However, the proposed product can be used over other global non-vegetated land surfaces since the product will weigh considerably more information from the DB algorithm which is designed to retrieve AOD accurately over non-vegetated surfaces. To support this hypothesis, one urban AERONET is also included in the validation experiment. Dataset and methods are described in Sections 2 and 3, respectively, and Sections 4 and 5 are about results and discussion, and conclusion, respectively.

\section{Dataset}

In this study, Terra-MODIS C6 level-2 operational aerosol products at $3 \mathrm{~km}$ (MOD04_3K) and $10 \mathrm{~km}$ (MOD04) spatial resolutions were downloaded from Level-1 and Atmosphere Archive \& Distribution System (LAADS) Distributed Active Archive Center (DAAC) (https: / ladsweb.nascom. nasa.gov/) to obtain $\mathrm{DT}_{3 \mathrm{~K}}$ and $\mathrm{DB}_{10 \mathrm{~K}} \mathrm{AOD}$ retrievals, respectively, for evaluation and development of the proposed merged $3 \mathrm{~km}$ DT and DB aerosol product (DTB $\left.{ }_{3 \mathrm{~K}}\right)$. The Terra-MODIS monthly level 3 Normalized Difference Vegetation Index (NDVI) product (MOD13A3) was downloaded to obtain the parameter " $1 \mathrm{~km} \mathrm{NDVI"} \mathrm{to} \mathrm{derive} \mathrm{average} \mathrm{NDVI} \mathrm{values} \mathrm{for} \mathrm{each} \mathrm{corresponding} \mathrm{validation} \mathrm{site}$ (Table 1). Aerosol Robotic Network (AERONET) $[10,11]$ cloud-screened and quality-assured (Level 2.0 Version 2) AOD data [12] were downloaded from http:/ / aeronet.gsfc.nasa.gov for 19 European sites from 2008 to 2012.

Table 1. Summary of the AERONET sites used in this study from 2008 to 2012.

\begin{tabular}{cccccc}
\hline Site & Latitude $\left({ }^{\circ} \mathbf{N}\right)$ & Longitude $\left({ }^{\circ} \mathbf{E}\right)$ & Elevation $(\mathbf{m})$ & Avg. NDVI & Country \\
\hline Aubiere LAMP & 45.76096 & 3.11107 & 423.0 & 0.36 & France \\
Avignon & 43.93275 & 4.87807 & 32.0 & 0.54 & France \\
Brussels & 50.78333 & 4.35000 & 120.0 & 0.59 & Belgium \\
Cabauw & 51.97100 & 4.92700 & -0.7 & 0.72 & Netherlands \\
Carpentras & 44.08333 & 5.05833 & 100.0 & 0.45 & France \\
Chilbolton & 51.14446 & 1.43698 & 88.0 & 0.60 & UK \\
Hamburg & 53.56833 & 9.97333 & 105.0 & 0.37 & Germany \\
Ispra & 45.80305 & 8.62670 & 235.0 & 0.57 & Italy \\
Kanzelhohe Obs. & 46.67800 & 13.90700 & 1526.0 & 0.65 & Austria \\
Leipzig & 51.35250 & 12.43528 & 125.0 & 0.44 & Germany \\
Lille & 50.61167 & 3.14167 & 60.0 & 0.45 & France \\
Minsk & 53.92000 & 27.60100 & 200.0 & 0.32 & Belarus \\
Moscow MSU MO & 55.70000 & 37.51000 & 192.0 & 0.31 & Russia \\
Munich University & 48.14800 & 11.57300 & 533.0 & 0.37 & Germany \\
OHP OBSERVATOIRE & 43.93500 & 5.71000 & 680.0 & 0.55 & France \\
Palaiseau & 48.70000 & 2.20833 & 156.0 & 0.57 & France \\
Paris & 48.86667 & 2.33333 & 50.0 & 0.15 & France \\
Rome Tor Vergata & 41.83955 & 12.64733 & 130.0 & 0.48 & Italy \\
Toravere & 58.25500 & 26.46000 & 70.0 & 0.50 & Estonia \\
\hline
\end{tabular}




\section{Methods}

$\mathrm{DT}_{3 \mathrm{~K}}$ and merged $\mathrm{DTB}_{3 \mathrm{~K}}$ AOD retrievals were validated from 2008 to 2012 against the 19 European AERONET sites. As the MODIS DT algorithm is designed to retrieve AOD over vegetated surfaces (NDVI > 0.3) [13], the AERONET sites selected for validation correspond with adjacent surfaces exhibiting NDVI values between 0.31 and 0.75 , except one (Paris) with NDVI of 0.15 that is an urban site (Table 1). The methodology of this study is based on the following steps:

(i) Only those $\mathrm{DT}_{3 \mathrm{~K}}$ and $\mathrm{DB}_{10 \mathrm{~K}} \mathrm{AOD}$ retrievals at $0.55 \mu \mathrm{m}$ passing recommended quality assurance $(\mathrm{AQ})$ checks $[13,16,37]$ were used (for DT, this corresponds to retrievals flagged $\mathrm{QA}=3$, and, for $\mathrm{DB}$, retrievals flagged $\mathrm{QA}=2$ or $\mathrm{QA}=3$ ). Therefore, the $\mathrm{DT}_{3 \mathrm{~K}}$ and $\mathrm{DB}_{10 \mathrm{~K}}$ highest-quality retrievals were obtained from the Scientific Data Set (SDS) "Optical_Depth_Land_And_Ocean" and "Deep_Blue_Aerosol_Optical_Depth_550_Land_Best_Estimate", respectively.

(ii) $\mathrm{DB}_{10 \mathrm{~K}} \mathrm{AOD}$ retrievals were resampled to $3 \mathrm{~km}$ spatial grid $\left(\mathrm{DB}_{3 \mathrm{k}}\right)$ onto the $\mathrm{DT}_{3 \mathrm{~K}}$ grid using the nearest neighbor interpolation algorithm $[65,66]$ to match and overlap pixels of $\mathrm{DB}_{3 \mathrm{~K}}$ with the pixels of $\mathrm{DT}_{3 \mathrm{~K}}$. As the $\mathrm{DB}$ algorithm first retrieves $\mathrm{AOD}$ at $1 \mathrm{~km}$ resolution, by finding the best match between satellite TOA reflectance and pre-calculated TOA reflectance stored in a LUT, all available pixels are then aggregated to $10 \mathrm{~km}$ resolution [16,37,38]. It is expected that resampling from 10 to $3 \mathrm{~km}$ will not affect the accuracy and quality of the DB AOD retrievals.

(iii) To reduce errors in $\mathrm{DT}_{3 \mathrm{~K}}$, the $\mathrm{DTB}_{3 \mathrm{k}}$ product is generated using the Simplified Merge Scheme (SMS) (DTB $\mathrm{M}_{1}$ in [39]). This technique is selected as it increases the number of collocations and decreases the errors, and is defined as "an average of the $\mathrm{DT}_{3 \mathrm{~K}}$ and $\mathrm{DB}_{3 \mathrm{~K}} \mathrm{AOD}$ retrievals or the available one with highest quality assurance flag" independent of the NDVI values [39]. This proposed technique differs from the operational $\mathrm{DTB}_{10 \mathrm{~K}}$ technique [13], which uses "an average of the $\mathrm{DT}_{10 \mathrm{~K}}$ and $\mathrm{DB}_{10 \mathrm{~K}} \mathrm{AOD}$ retrievals or available one for only $0.2<\mathrm{NDVI}<0.3^{\prime \prime}$. Instead, the proposed technique uses "an average the $\mathrm{DT}_{10 \mathrm{~K}}$ and $\mathrm{DB}_{10 \mathrm{~K}} \mathrm{AOD}$ retrievals or available one" for all available NDVI values.

(iv) AERONET AOD is interpolated to $0.55 \mu \mathrm{m}$ using a standard Ångström exponent $(\alpha)$ extrapolation [37], as the project does not provide AOD measurements directly at this common MODIS wavelength.

(v) To increase the number of samples for validation, collocations are defined as the average of at least two AERONET AOD measurements between 10:00 and 12:00 local solar time and at least two pixels of MODIS AOD observations within a sampling window of 3 pixels $\times 3$ pixels (average of 9 pixels) centered on the AERONET site. (i.e., an average within a $9 \mathrm{~km} \times 9 \mathrm{~km}$ region).

(vi) Retrieval errors are reported using the expected error (EE) of the DT algorithm at $3 \mathrm{~km}$ resolution over land [32], root mean square error (RMSE), and mean bias (MB). To compare $\mathrm{DT}_{3 \mathrm{~K}}$ and $\mathrm{DTB}_{3 \mathrm{~K}}$ statistically, the percent relative differences in N, EE Equation (1), RMSE Equation (2), MB Equation (3), and R Equation (4) are calculated using Equation (5). These relationships are defined as

$$
\begin{gathered}
\mathrm{EE}= \pm\left(0.05+0.20 \times \operatorname{AOD}_{(\text {AERONET })}\right) \\
\mathrm{RMSE}=\sqrt{\frac{1}{n} \sum_{i=1}^{n}\left(\text { AOD }_{(M O D I S) i}-\text { AOD }_{(\text {AERONET }) i}\right)^{2}} \\
\mathrm{MB}=\overline{A O D}_{(\text {MODIS })}-\overline{A O D}_{(\text {AERONET })} \\
\mathrm{R}=\frac{n \sum A E R O N E T_{i} \times \text { MODIS }_{i}-\sum A E \text { RONET }_{i} \times \sum M O D I S_{i}}{\sqrt{\left[n \sum\left(\text { AERONET }_{i}\right)^{2}-\left(\sum A E R O N E T_{i}\right)^{2}\right] \times\left[n \sum\left(\text { MODIS }_{i}\right)^{2}-\left(\sum \text { MODIS }_{i}\right)^{2}\right]}}
\end{gathered}
$$

and

$$
\% \text { Relative Difference }=\left(\frac{D T_{3 K}-D T B_{3 K}}{D T_{3 K}}\right) \times 100
$$




\section{Results and Discussion}

\subsection{Validation of the $D T_{3 K}$ and $D T B_{3 K} A O D$ Products at Regional Scale}

$\mathrm{DT}_{3 \mathrm{~K}}$ and $\mathrm{DTB}_{3 \mathrm{~K}}$ AOD retrievals were validated from 2008 to 2012 (Figure 1 and Table 2) against AERONET. In Figure 1, red and black colors represent the coincident $\mathrm{DT}_{3 \mathrm{~K}}$ and $\mathrm{DTB}_{3 \mathrm{~K}}$ observations, respectively (dashed lines $=\mathrm{EE}$ envelopes, and the black solid line $=1: 1$ line). Figure 1 shows that the $\mathrm{DT}_{3 \mathrm{~K}}$ AOD retrievals, in general, overestimate at all of the sites, although large variance was observed between them overall. This overestimation of $\mathrm{AOD}$ retrievals by $\mathrm{DT}_{3 \mathrm{~K}}$ was observed at 13 out of 19 sites, while AOD retrievals at only six sites meet the requirement of the $E E$ ( $>68 \%$ or $69 \%$ to $88 \%$ of the retrievals were within the EE). The greatest uncertainties were observed at Paris (NDVI = 0.15), Moscow_MU_MO (NDVI = 0.31), Leipzig (NDVI =0.44), and Minsk (NDVI = 0.32), with only 8\%, 14\%, $26 \%$ and $27 \%$ of the retrievals, respectively, being within EE (Figure 1 and Table 2 ). This overestimation, occurring for both low and high aerosol loadings, probably implies an underestimation of the surface reflectance by the VIS vs. $2.11 \mu \mathrm{m}$ relationship, and potentially an error in the aerosol schemes used in the LUT. Previous studies reported similar errors in the $\mathrm{DT}_{3 \mathrm{~K}} \mathrm{AOD}$ retrievals over different parts of the globe [32-34,36]. This is also similar to the DT C6 algorithm at $10 \mathrm{~km}$, which overestimates with positive offset $[34-36,67,68]$.

Table 2. Validation summary of the $\mathrm{DT}_{3 \mathrm{~K}}$ and $\mathrm{DTB}_{3 \mathrm{~K}}$ AOD retrievals.

\begin{tabular}{|c|c|c|c|c|c|}
\hline Site & $\mathbf{N}$ & \% Above/Within/Below EE & RMSE & MB & $\mathbf{R}$ \\
\hline \multicolumn{6}{|c|}{$\mathrm{DT}_{3 \mathrm{~K}}$ AOD Product } \\
\hline Aubiere LAMP & 232 & $40 / 60 / 00$ & 0.116 & 0.073 & 0.731 \\
\hline Avignon & 783 & $34 / 66 / 00$ & 0.092 & 0.064 & 0.853 \\
\hline Brussels & 211 & $33 / 67 / 00$ & 0.104 & 0.063 & 0.817 \\
\hline Cabauw & 219 & $19 / 78 / 03$ & 0.093 & 0.040 & 0.837 \\
\hline Carpentras & 258 & $31 / 69 / 00$ & 0.078 & 0.057 & 0.861 \\
\hline Chilbolton & 241 & $24 / 75 / 01$ & 0.101 & 0.041 & 0.728 \\
\hline Hamburg & 149 & $66 / 34 / 00$ & 0.154 & 0.127 & 0.835 \\
\hline Ispra & 183 & $09 / 88 / 03$ & 0.078 & 0.012 & 0.913 \\
\hline Kanzelhohe Obs. & 96 & $43 / 53 / 00$ & 0.092 & 0.067 & 0.623 \\
\hline Leipzig & 293 & $74 / 26 / 00$ & 0.164 & 0.137 & 0.832 \\
\hline Lille & 303 & $58 / 40 / 02$ & 0.139 & 0.107 & 0.793 \\
\hline Minsk & 161 & $73 / 27 / 00$ & 0.163 & 0.135 & 0.828 \\
\hline Moscow MSU MO & 173 & $86 / 14 / 00$ & 0.200 & 0.179 & 0.888 \\
\hline Munich University & 257 & $59 / 40 / 01$ & 0.128 & 0.104 & 0.794 \\
\hline OHP OBSERVATOIRE & 765 & $24 / 76 / 00$ & 0.070 & 0.045 & 0.834 \\
\hline Palaiseau & 354 & $38 / 61 / 01$ & 0.102 & 0.066 & 0.787 \\
\hline Paris & 212 & $92 / 08 / 00$ & 0.362 & 0.311 & 0.533 \\
\hline Rome Tor Vergata & 675 & $54 / 45 / 01$ & 0.122 & 0.096 & 0.778 \\
\hline Toravere & 261 & $25 / 74 / 01$ & 0.098 & 0.053 & 0.811 \\
\hline All sites & 5826 & $43 / 56 / 01$ & 0.131 & 0.085 & 0.769 \\
\hline \multicolumn{6}{|c|}{ DTB $_{3 K}$ AOD Product } \\
\hline Aubiere LAMP & 240 & $20 / 79 / 01$ & 0.100 & 0.043 & 0.724 \\
\hline Avignon & 897 & $15 / 84 / 01$ & 0.068 & 0.023 & 0.809 \\
\hline Brussels & 223 & $23 / 77 / 00$ & 0.095 & 0.048 & 0.802 \\
\hline Cabauw & 266 & $14 / 82 / 04$ & 0.088 & 0.019 & 0.817 \\
\hline Carpentras & 268 & $20 / 80 / 00$ & 0.067 & 0.037 & 0.828 \\
\hline Chilbolton & 254 & $15 / 83 / 02$ & 0.095 & 0.022 & 0.717 \\
\hline Hamburg & 188 & $19 / 80 / 01$ & 0.094 & 0.036 & 0.804 \\
\hline Ispra & 276 & $04 / 85 / 11$ & 0.076 & -0.019 & 0.897 \\
\hline Kanzelhohe Obs. & 120 & $24 / 73 / 03$ & 0.084 & 0.027 & 0.552 \\
\hline Leipzig & 324 & $24 / 74 / 02$ & 0.120 & 0.063 & 0.760 \\
\hline Lille & 325 & $31 / 68 / 01$ & 0.107 & 0.063 & 0.787 \\
\hline Minsk & 178 & $34 / 65 / 01$ & 0.122 & 0.066 & 0.767 \\
\hline
\end{tabular}


Table 2. Cont.

\begin{tabular}{cccccc}
\hline Site & $\mathbf{N}$ & $\begin{array}{c}\text { \% Above/Within/Below EE } \\
\text { DT }_{\text {3K }} \text { AOD Product }\end{array}$ & RMSE & MB & R \\
\hline Moscow MSU MO & 202 & $30 / 68 / 02$ & 0.151 & 0.072 & 0.932 \\
Munich University & 286 & $19 / 79 / 02$ & 0.082 & 0.022 & 0.768 \\
OHP OBSERVATOIRE & 779 & $17 / 83 / 00$ & 0.062 & 0.030 & 0.803 \\
Palaiseau & 369 & $18 / 79 / 03$ & 0.083 & 0.025 & 0.751 \\
Paris & 304 & $34 / 63 / 03$ & 0.188 & 0.083 & 0.495 \\
Rome Tor Vergata & 717 & $28 / 71 / 01$ & 0.097 & 0.052 & 0.734 \\
Toravere & 276 & $26 / 73 / 01$ & 0.094 & 0.051 & 0.802 \\
All sites & 6492 & $21 / 77 / 02$ & 0.097 & 0.039 & 0.801 \\
\hline
\end{tabular}
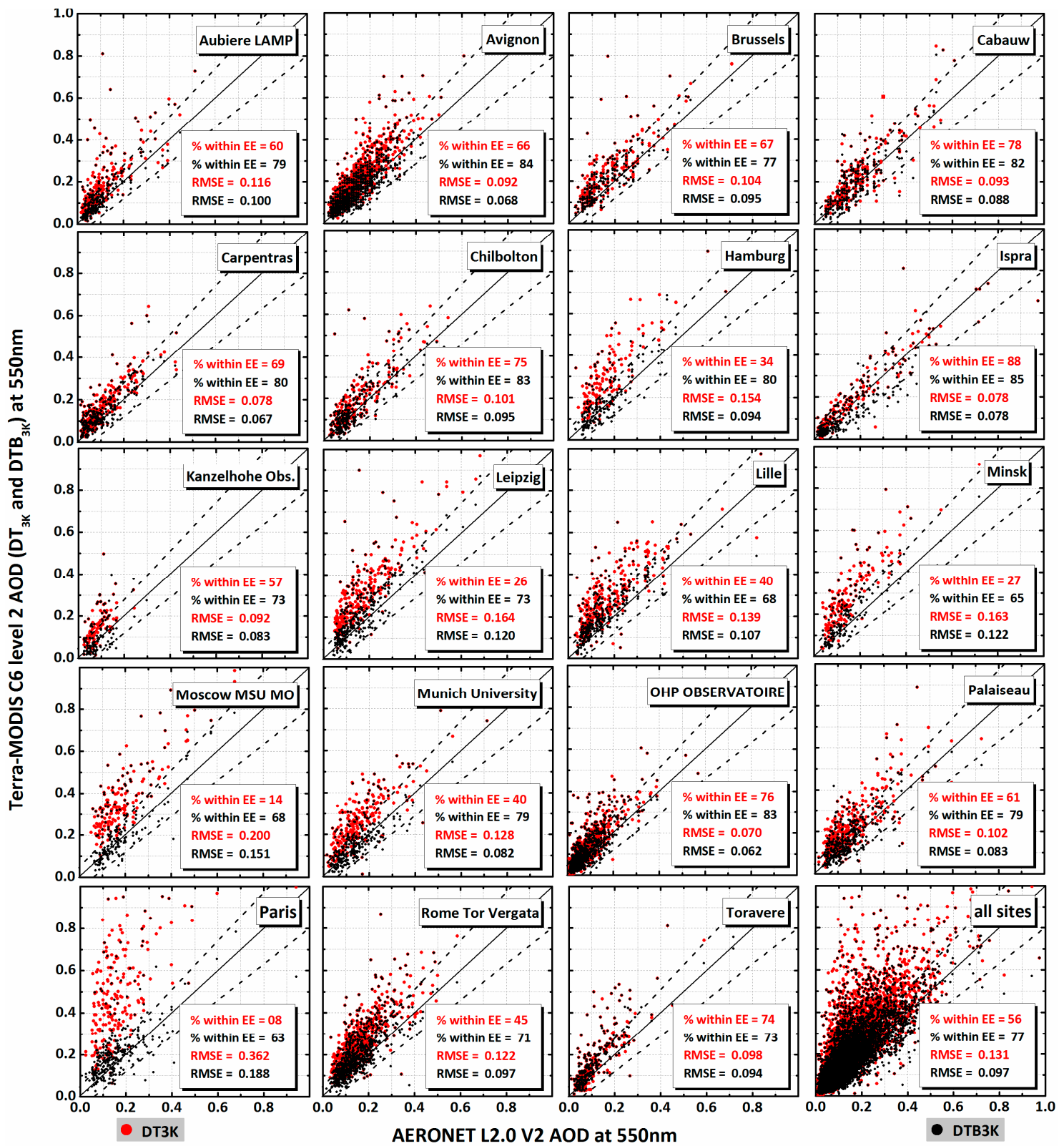

Figure 1. Validation of $\mathrm{DT}_{3 \mathrm{~K}}$ and $\mathrm{DTB}_{3 \mathrm{~K}}$ AOD products against 19 AERONET sites located at vegetated surfaces (NDVI > 0.30), except Paris (NDVI < 0.20), from 2008 to 2012. 
The aggregated results of all sites show a large and significant overestimation in the $\mathrm{DT}_{3 \mathrm{~K}} \mathrm{AOD}$ retrievals, as $43 \%$ of the retrievals were above EE (Table 2). All these sites have different surface characteristics. For example, Paris is a pure urban site, whereas Leipzig is dominated by vegetated surfaces. For Paris and Leipzig, the slope between $\mathrm{DT}_{3 \mathrm{~K}}$ and AERONET was significantly greater than one (Paris $=1.99$ and Leipzig $=1.47$ ), which probably suggests too much absorption in the aerosol model used in the LUT $[38,69]$. However, both generally experience a wide range of aerosol loading conditions. Thus, selection of an accurate aerosol model is important for accurate high AOD retrievals [13]. Overall, the performance of $\mathrm{DT}_{3 \mathrm{~K}}$ was relatively poor over the vegetated surfaces (NDVI > 0.30), as only $56 \%$ of the retrievals were within EE with RMSE of 0.131 and MB of 0.085 . This is an important distinction, though, as the point of designing the retrieval was ultimately more accurate AOD over such surfaces.

Validation of the $\mathrm{DTB}_{3 \mathrm{~K}} \mathrm{AOD}$ retrievals show significant improvement in retrieval quality, as the percentage of retrievals within EE increased and RMSE and MB decreased at each site (Figure 1 and Table 2). For the Paris, Moscow_MU_MO, Leipzig, and Minsk sites, for instance, the percentage of retrievals within EE increased remarkably from $8 \%$ to $63 \%, 14 \%$ to $68 \%, 26 \%$ to $73 \%$, and $27 \%$ to $65 \%$, respectively; RMSE decreased from 0.362 to $0.188,0.200$ to $0.151,0.164$ to 0.120 , and 0.163 to 0.122 , respectively; and $\mathrm{MB}$ decreased from 0.311 to $0.083,0.179$ to $0.072,0.137$ to 0.063 , and 0.135 to 0.066 (Table 2), respectively. These results suggest that the $\mathrm{DB}$ algorithm performs better at these sites compared with DT and the contribution of the DB AOD retrievals in the $\mathrm{DTB}_{3 \mathrm{~K}}$ retrievals significantly improves the retrieval quality and reduces error. Again, the advantage of using the average of both DT and DB AOD retrievals is to minimize the error in the DT C6 algorithm [39].

For all sites, $77 \%$ of the $\mathrm{DTB}_{3 \mathrm{~K}}$ AOD retrievals were within $\mathrm{EE}$, which is $38 \%$ higher than the $\mathrm{DT}_{3 \mathrm{~K}}$ AOD retrievals, RMSE and MB decreased from 0.131 to 0.097 and 0.087 to 0.039 , which are $26 \%$ and $54 \%$, respectively, lower than the $\mathrm{DT}_{3 \mathrm{~K}}$. These results suggest that a merged $\mathrm{DTB}_{3 \mathrm{~K}} \mathrm{AOD}$ product exhibits better retrieval quality than the $\mathrm{DT}_{3 \mathrm{~K}}$ and can thus be applied with greater confidence for air quality studies at the relatively finer scales.

\subsection{Validation of the $D T_{3 K}$ and $D T B_{3 K} A O D$ Products at Local Scales}

The performance of the $\mathrm{DT}_{3 \mathrm{~K}}$ and $\mathrm{DTB}_{3 \mathrm{~K}}$ AOD products was further evaluated in terms of improvement in percentage of retrievals within EE, spatiotemporal data coverage, RMSE and MB and $\mathrm{R}$ at each AERONET site based on the following criteria [39]: if the relative difference using Equation (5) is (a) within $10 \%$ for the percentage of retrievals within EE; (b) within $20 \%$ for the data count $(\mathrm{N})$; (c) within 5\% for RMSE; (d) within 5\% for MB; and (e) within 10\% for R, then the $\mathrm{DT}_{3 \mathrm{~K}}$ and $\mathrm{DTB}_{3 \mathrm{~K}}$ are considered to perform equally well at that site, and these sites are denoted by a "plus" symbol in Figure 2. In Figure 2, $\mathrm{DT}_{3 \mathrm{~K}}$ and $\mathrm{DTB}_{3 \mathrm{~K}}$ are represented by "triangle" and "circle" symbols, respectively, when they performed better over the individual sites, and color variations represent the magnitude of the relative difference $(\%)$ between the $\mathrm{DT}_{3 \mathrm{~K}}$ and $\mathrm{DTB}_{3 \mathrm{~K}}$ AOD products. The point of this analysis is to highlight the robustness of the AOD product with respect to each statistical parameter for each individual site.

For the percentage of AOD retrievals within EE, the $\mathrm{DTB}_{3 \mathrm{~K}}$ AOD product performed well, as 15 out of 19 sites showed improvement and the percentage of AOD retrievals within EE was increased by $11 \%$ to $>100 \%$ compared with the $\mathrm{DT}_{3 \mathrm{~K}}$ AOD product (Figure $2 \mathrm{a}$ ). There were only four sites where $\mathrm{DT}_{3 \mathrm{~K}}$ and $\mathrm{DTB}_{3 \mathrm{~K}}$ performed equally, as the relative difference of the percentage of retrievals within $\mathrm{EE}$ is less than $10 \%$. Overall, the $\mathrm{DTB}_{3 \mathrm{~K}}$ method performed well and significantly improved retrieval quality, as the percentage of AOD retrievals within EE increased due to the contribution of the DB AOD retrievals.

For the data count, or number of collocations, the $\mathrm{DT}_{3 \mathrm{~K}}$ and $\mathrm{DTB}_{3 \mathrm{~K}}$ methods performed equally at 14 out of 19 sites, as the relative difference of data counts is within $20 \%$ (Figure 2b). For the remaining five sites, $\mathrm{DTB}_{3 \mathrm{~K}}$ performed well compared with $\mathrm{DT}_{3 \mathrm{~K}}$ as the data count increased by $21 \%$ 
to $60 \%$. This indicates that the $\mathrm{DTB}_{3 \mathrm{~K}}$ method is likely more skillful than the $\mathrm{DT}_{3 \mathrm{~K}}$ method in terms of spatiotemporal data coverage.
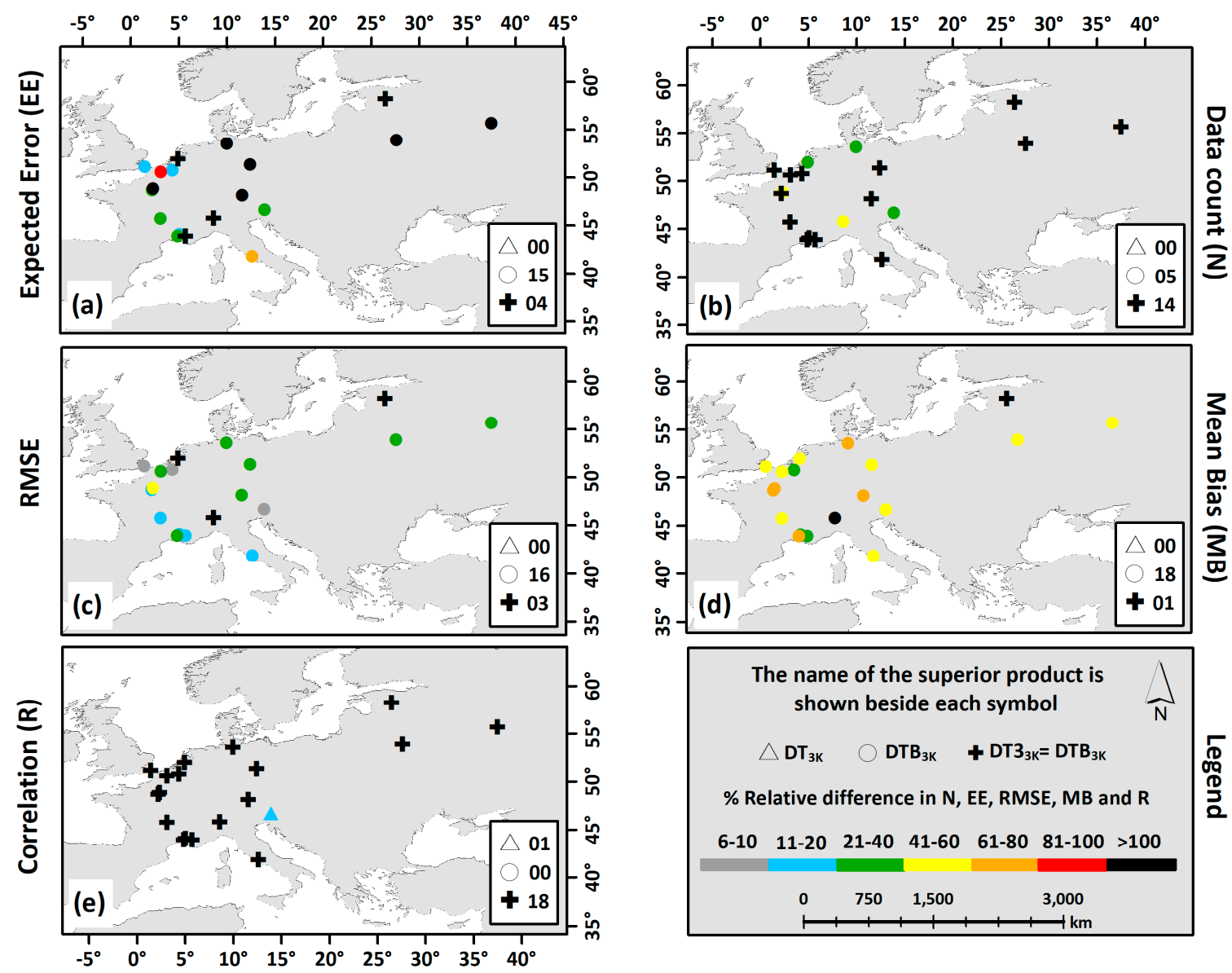

Figure 2. Maps showing the best performing retrieval at AERONET sites for the following evaluation statistics: (a) percentage within the EE; (b) data count $(\mathrm{N})$; (c) root mean square error (RMSE); (d) mean bias (MB); and (e) correlation coefficient (R).

For RMSE and $M B$, the $\mathrm{DTB}_{3 \mathrm{~K}}$ method significantly reduced the errors at 16 (Figure $2 \mathrm{c}$ ) and 18 (Figure 2d) sites, respectively, compared with $\mathrm{DT}_{3 \mathrm{~K}}$. The RMSE and MB reduced by 6 to $60 \%$ and 21 to $>100 \%$, respectively. There were only three (one) sites where both methods exhibit the same RMSE (MB). These results suggest that $\mathrm{DTB}_{3 \mathrm{~K}}$ is robust, with lower RMSE and MB errors than the $\mathrm{DT}_{3 \mathrm{~K}}$ retrievals.

For correlation, the $\mathrm{DT}_{3 \mathrm{~K}}$ and $\mathrm{DTB}_{3 \mathrm{~K}}$ methods performed equally at 18 out of 19 sites, as the relative difference was within $10 \%$ (Figure 2e). There was only one site where the $\mathrm{DT}_{3 \mathrm{~K}}$ AOD retrievals have a better correlation with the AERONET AOD retrievals than the $\mathrm{DTB}_{3 \mathrm{~K}}$ AOD retrievals as the relative difference was between $11 \%$ and $20 \%$. Overall, both methods performed equally in terms of correlation.

In full, these results suggest that the $\mathrm{DTB}_{3 \mathrm{~K}}$ method is robust, more efficient and performed better at relatively finer scales, with larger data count percentages within EE, greater data counts overall, and lower RMSE and MB than $\mathrm{DT}_{3 \mathrm{~K}}$.

\section{Summary and Conclusions}

The Moderate Resolution Imaging Spectroradiometer (MODIS) Collection 6 aerosol product provides global aerosol optical depth (AOD) observations over land at $3 \mathrm{~km}$ and $10 \mathrm{~km}$ spatial 
resolutions based on the Dark Target (DT) algorithms, and at $10 \mathrm{~km}$ resolution based on the Deep Blue (DB) algorithm. The DT and DB algorithms have different spatial coverage of AOD observations over land due to differences in their retrieval approaches (i.e. pixel selection, cloud screening and surface reflectance estimation method). $\mathrm{DT}_{3 \mathrm{~K}}$ exhibits large errors over urban or non-vegetated surfaces, as the DT algorithm is designed to retrieve AOD over vegetated surfaces. Therefore, the objectives of this study included developing a new DT and DB merged aerosol product on a $3 \mathrm{~km}$ grid, which can reduce the errors and increase the spatiotemporal coverage by providing AOD observations for those surface types and regions where either of each (DT and DB) were unable to provide due to pixel selection criteria and cloud mask.

For this analysis: (i) only high quality-assured AOD observations were obtained from the Scientific Data Sets (SDS), including "Optical_Depth_Land_And_Ocean" and “Deep_Blue_Aerosol_Optical_Depth_550_Land_Best_Estimate" for $\mathrm{DT}_{3 \mathrm{~K}}$ and $\mathrm{DB}_{10 \mathrm{~K}}$, respectively; (ii) the $\mathrm{DB}_{10 \mathrm{~K}} \mathrm{AOD}$ retrievals were resampled to $3 \mathrm{~km}$ grid using nearest neighbor interpolation algorithm; and (iii) they were merged with $\mathrm{DT}_{3 \mathrm{~K}}$ AOD retrievals using Simplified Merge Scheme (SMS) defined as "an average of the $\mathrm{DT}_{3 \mathrm{~K}}$ and $\mathrm{DB}_{3 \mathrm{~K}}$ AOD retrievals or the available one with highest quality assurance flag". DT $3 \mathrm{~K}$ and $\mathrm{DTB}_{3 \mathrm{~K}}$ AOD retrievals were validated from 2008 to 2012 against cloud-screened and quality-assured (Level 2.0 Version 2) AOD measurements obtained from the 19 AERONET sites in Europe located over the vegetated and non-vegetated surfaces.

Our primary conclusions are:

(i) $\mathrm{DT}_{3 \mathrm{~K}} \mathrm{AOD}$ retrievals were overestimated over vegetated surfaces for both low and high aerosol loadings.

(ii) The overestimation might be caused by the underestimation of the surface reflectance and inappropriate aerosol model.

(iii) Only $56 \%$ retrievals of the $\mathrm{DT}_{3 \mathrm{~K}}$ were within the $\mathrm{EE}$ which indicates that the $\mathrm{DT}_{3 \mathrm{~K}}$ product does not meet the requirements of the EE.

(iv) The $\mathrm{DTB}_{3 \mathrm{~K}}$ method significantly improved the retrieval quality as the percentage of the retrievals and data counts were increased, and RMSE and MB were decreased.

(v) The contribution of $\mathrm{DB} A O D$ retrievals in the $\mathrm{DTB}_{3 \mathrm{~K}}$ helped to reduce the overestimation in the $\mathrm{DT}_{3 \mathrm{~K}}$ AOD retrievals for both low and high aerosol loadings.

(vi) The percentage within the EE for the $\mathrm{DTB}_{3 \mathrm{~K}}$ retrievals increased up to $77 \%$ which indicates that the $\mathrm{DTB}_{3 \mathrm{~K}}$ product meets the requirements of the $\mathrm{EE}$, and this is a $38 \%$ relative increase over the $\mathrm{DT}_{3 \mathrm{~K}}$ AOD retrievals.

(vii) The $\mathrm{DBT}_{3 \mathrm{~K}}$ method reduced the RMSE and MB errors by $26 \%$ and $54 \%$, respectively, for all sites.

Overall, the $\mathrm{DTB}_{3 \mathrm{~K}}$ merged method is robust and performed better over vegetated and non-vegetated land surfaces than the $\mathrm{DT}_{3 \mathrm{~K}}$ algorithm, and is recommended for air quality and climate-related studies in such land-surface regions.

Acknowledgments: The authors acknowledge NASA Goddard Space Flight Center for MODIS data, and Principal Investigators of AERONET sites. We are thankful to Devin White (Oak Ridge National Laboratory) for MODIS Conversion Tool Kit (MCTK). The National Key Research and Development Program of China (No. 2016YFC1400901), the National Programme on Global Change and Air-sea Interaction (GASI-03-03-01-01) and National Science Foundation of China (NSFC) (Project No. 41374013) have sponsored this research.

Author Contributions: Muhammad Bilal designed and wrote the paper; Zhongfeng Qiu, James R. Campbell, and Scott N. Spak reviewed and modified the paper; and Shen Xiaojing and Majid Nazeer helped in data processing.

Conflicts of Interest: The authors declare no conflict of interest. 


\section{References}

1. Kaufman, Y.J.; Tanré, D.; Boucher, O. A satellite view of aerosols in the climate system. Nature 2002, 419, 215-223. [CrossRef] [PubMed]

2. Cheung, H.-C.; Wang, T.; Baumann, K.; Guo, H. Influence of regional pollution outflow on the concentrations of fine particulate matter and visibility in the coastal area of southern China. Atmos. Environ. 2005, 39, 6463-6474. [CrossRef]

3. Park, R.J.; Jacob, D.J.; Kumar, N.; Yantosca, R.M. Regional visibility statistics in the United States: Natural and transboundary pollution influences, and implications for the Regional Haze Rule. Atmos. Environ. 2006, 40, 5405-5423. [CrossRef]

4. Bell, M.L.; Ebisu, K.; Belanger, K. Ambient air pollution and low birth weight in Connecticut and Massachusetts. Environ. Health Perspect. 2007, 115, 1118-1124. [CrossRef] [PubMed]

5. Dominici, F.; Peng, R.D.; Bell, M.L.; Pham, L.; McDermott, A.; Zeger, S.L.; Samet, J.M. Fine particulate air pollution and hospital admission for cardiovascular and respiratory diseases. JAMA 2006, 295, 1127-1134. [CrossRef] [PubMed]

6. Götschi, T.; Heinrich, J.; Sunyer, J.; Künzli, N. Long-term effects of ambient air pollution on lung function: A review. Epidemiology 2008, 19, 690-701. [CrossRef] [PubMed]

7. Pope, C.A.; Burnett, R.T.; Thun, M.J.; Calle, E.E.; Krewski, D.; Ito, K.; Thurston, G.D. Lung cancer, cardiopulmonary mortality, and long-term exposure to fine particulate air pollution. JAMA 2002, 287, 1132-1141. [CrossRef] [PubMed]

8. Pope, C.A.; Dockery, D.W. Health effects of fine particulate air pollution: Lines that connect. J. Air Waste Manag. Assoc. 2006, 56, 709-742. [CrossRef]

9. Pope, C.A.; Ezzati, M.; Dockery, D.W. Fine-particulate air pollution and life expectancy in the United States. N. Engl. J. Med. 2009, 360, 376-386. [CrossRef] [PubMed]

10. Holben, B.N.; Eck, T.F.; Slutsker, I.; Tanré, D.; Buis, J.P.; Setzer, A.; Vermote, E.; Reagan, J.A.; Kaufman, Y.J.; Nakajima, T.; et al. Aeronet-A federated instrument network and data archive for aerosol characterization. Remote Sens. Environ. 1998, 66, 1-16. [CrossRef]

11. Holben, N.; Tanr, D.; Smirnov, A.; Eck, T.F.; Slutsker, I.; Newcomb, W.W.; Schafer, J.S.; Chatenet, B.; Lavenu, F.; Kaufman, J.; et al. An emerging ground-based aerosol climatology: Aerosol optical depth from AERONET . J. Geophys. Res. Atmos. 2001, 106, 12067-12097. [CrossRef]

12. Smirnov, A.; Holben, B.N.; Eck, T.F.; Dubovik, O.; Slutsker, I. Cloud-screening and quality control algorithms for the AERONET database. Remote Sens. Environ. 2000, 73, 337-349. [CrossRef]

13. Levy, R.C.; Mattoo, S.; Munchak, L.A.; Remer, L.A.; Sayer, A.M.; Patadia, F.; Hsu, N.C. The Collection 6 MODIS aerosol products over land and ocean. Atmos. Meas. Tech. 2013, 6, 2989-3034. [CrossRef]

14. Aaron, V.D.; Randall, V.M.; Robert, J.D.S.; Richard, T.B. High-resolution satellite-derived PM2.5 from optimal estimation and geographically weighted regression over North America. Environ. Sci. Technol. 2015, 49, 10482-10491.

15. Hauser, A.; Oesch, D.; Foppa, N.; Wunderle, S. NOAA AVHRR derived aerosol optical depth over land. J. Geophys. Res. 2005, 110, D08204. [CrossRef]

16. Hsu, N.C.; Jeong, M.-J.; Bettenhausen, C.; Sayer, A.M.; Hansell, R.; Seftor, C.S.; Huang, J.; Tsay, S.-C. Enhanced deep blue aerosol retrieval algorithm: The second generation. J. Geophys. Res. Atmos. 2013, 118, 9296-9315. [CrossRef]

17. Jackson, J.M.; Liu, H.; Laszlo, I.; Kondragunta, S.; Remer, L.A.; Huang, J.; Huang, H.-C. Suomi-NPP VIIRS aerosol algorithms and data products. J. Geophys. Res. Atmos. 2013, 118, 12673-12689. [CrossRef]

18. Kahn, R.A.; Gaitley, B.J.; Garay, M.J.; Diner, D.J.; Eck, T.F.; Smirnov, A.; Holben, B.N. Multiangle imaging spectroradiometer global aerosol product assessment by comparison with the aerosol robotic network. J. Geophys. Res. 2010, 115, D23209. [CrossRef]

19. Kahn, R.A.; Gaitley, B.J.; Martonchik, J.V.; Diner, D.J.; Crean, K.A.; Holben, B. Multiangle Imaging Spectroradiometer (MISR) global aerosol optical depth validation based on 2 years of coincident Aerosol Robotic Network (AERONET) observations. J. Geophys. Res. 2005, 110, D10S04. [CrossRef]

20. Liu, H.; Remer, L.A.; Huang, J.; Huang, H.-C.; Kondragunta, S.; Laszlo, I.; Oo, M.; Jackson, J.M. Preliminary evaluation of S-NPP VIIRS aerosol optical thickness. J. Geophys. Res. Atmos. 2014, 119, 3942-3962. [CrossRef] 
21. Remer, L.a.; Kaufman, Y.J.; Tanré, D.; Mattoo, S.; Chu, D.a.; Martins, J.V.; Li, R.-R.; Ichoku, C.; Levy, R.C.; Kleidman, R.G.; et al. The MODIS aerosol algorithm, products, and validation. J. Atmos. Sci. 2005, 62, 947-973. [CrossRef]

22. Riffler, M.; Popp, C.; Hauser, A.; Fontana, F.; Wunderle, S. Validation of a modified avhrr aerosol optical depth retrieval algorithm over central europe. Atmos. Meas. Tech. 2010, 3, 1255-1270. [CrossRef]

23. Sayer, A.M.; Hsu, N.C.; Bettenhausen, C.; Jeong, M.-J.; Holben, B.N.; Zhang, J. Global and regional evaluation of over-land spectral aerosol optical depth retrievals from SeaWiFS. Atmos. Meas. Tech. 2012, 5, 1761-1778. [CrossRef]

24. Torres, O.; Bhartia, P.K.; Herman, J.R.; Sinyuk, A.; Ginoux, P.; Holben, B. A long-term record of aerosol optical depth from toms observations and comparison to AERONET measurements. J. Atmos. Sci. 2002, 59, 398-413. [CrossRef]

25. Torres, O.; Tanskanen, A.; Veihelmann, B.; Ahn, C.; Braak, R.; Bhartia, P.K.; Veefkind, P.; Levelt, P. Aerosols and surface UV products from ozone monitoring instrument observations: An overview. J. Geophys. Res. 2007, 112, D24S47. [CrossRef]

26. Vidot, J.; Santer, R.; Aznay, O. Evaluation of the meris aerosol product over land with AERONET. Atmo. Chem. Phys. 2008, 8, 7603-7617. [CrossRef]

27. Kaufman, Y.J.; Tanr, D.; Remer, L.A.; Vermote, E.F.; Chu, A. Operational remote sensing of tropospheric aerosol over land from EOS moderate resolution imaging spectroradiometer after the launch of MODIS the distribution. J. Geophys. Res. Atmos. 1997, 102, 17051-17067. [CrossRef]

28. Levy, R.C.; Remer, L.a.; Mattoo, S.; Vermote, E.F.; Kaufman, Y.J. Second-generation operational algorithm: Retrieval of aerosol properties over land from inversion of moderate resolution imaging spectroradiometer spectral reflectance. J. Geophys. Res. 2007, 112, D13211. [CrossRef]

29. Tanré, D.; Kaufman, Y.J.; Herman, M.; Mattoo, S. Remote sensing of aerosol properties over oceans using the MODIS/EOS spectral radiances. J. Geophys. Res. Atmos. 1997, 102, 16971-16988. [CrossRef]

30. Hsu, N.C.; Tsay, S.-C.; King, M.D.; Herman, J.R. Aerosol properties over bright-reflecting source regions. IEEE Trans. Geosci. Remote Sens. 2004, 42, 557-569. [CrossRef]

31. Hsu, N.C.; Tsay, S.-C.; King, M.D.; Herman, J.R. Deep blue retrievals of asian aerosol properties during ACE-Asia. IEEE Trans. Geosci. Remote Sens. 2006, 44, 3180-3195. [CrossRef]

32. Remer, L.A.; Mattoo, S.; Levy, R.C.; Munchak, L.A. MODIS 3 km aerosol product: Algorithm and global perspective. Atmos. Meas. Tech. 2013, 6, 1829-1844. [CrossRef]

33. Munchak, L.A.; Levy, R.C.; Mattoo, S.; Remer, L.A.; Holben, B.N.; Schafer, J.S.; Hostetler, C.A.; Ferrare, R.A. Modis $3 \mathrm{~km}$ aerosol product: Applications over land in an urban/suburban region. Atmos. Meas. Tech. 2013, 6, 1747-1759. [CrossRef]

34. Livingston, J.M.; Redemann, J.; Shinozuka, Y.; Johnson, R.; Russell, P.B.; Zhang, Q.; Mattoo, S.; Remer, L.; Levy, R.; Munchak, L.; et al. Comparison of MODIS $3 \mathrm{~km}$ and $10 \mathrm{~km}$ resolution aerosol optical depth retrievals over land with airborne sunphotometer measurements during arctas summer 2008. Atmo. Chem. Phys. 2014, 14, 2015-2038. [CrossRef]

35. Bilal, M.; Nichol, J.E. Evaluation of MODIS aerosol retrieval algorithms over the Beijing-Tianjin-Hebei region during low to very high pollution events. J. Geophys. Res. Atmos. 2015, 120, 7941-7957. [CrossRef]

36. Nichol, J.; Bilal, M. Validation of MODIS $3 \mathrm{~km}$ resolution aerosol optical depth retrievals over Asia. Remote Sens. 2016, 8, 328. [CrossRef]

37. Sayer, A.M.; Hsu, N.C.; Bettenhausen, C.; Jeong, M.-J. Validation and uncertainty estimates for MODIS Collection 6 "deep blue" aerosol data. J. Geophys. Res. Atmos. 2013, 118, 7864-7872. [CrossRef]

38. Sayer, A.M.; Munchak, L.A.; Hsu, N.C.; Levy, R.C.; Bettenhausen, C.; Jeong, M.J. MODIS Collection 6 aerosol products: Comparison between Aqua's e-deep blue, dark target, and "merged" data sets, and usage recommendations. J. Geophys. Res. Atmos. 2014, 119, 13965-13989. [CrossRef]

39. Bilal, M.; Nichol, J.; Wang, L. New customized methods for improvement of the MODIS C6 dark target and deep blue merged aerosol product. Remote Sens. Environ. 2017, 197, 115-124. [CrossRef]

40. Tao, M.; Chen, L.; Wang, Z.; Tao, J.; Che, H.; Wang, X.; Wang, Y. Comparison and evaluation of the MODIS Collection 6 aerosol data in China. J. Geophys. Res. Atmos. 2015, 120, 6992-7005. [CrossRef]

41. Mhawish, A.; Banerjee, T.; Broday, D.M.; Misra, A.; Tripathi, S.N. Evaluation of MODIS Collection 6 aerosol retrieval algorithms over indo-gangetic plain: Implications of aerosols types and mass loading. Remote Sens. Environ. 2017, 201, 297-313. [CrossRef] 
42. Bilal, M.; Nazeer, M.; Nichol, J.E. Validation of MODIS and VIIRS derived aerosol optical depth over complex coastal waters. Atmos. Res. 2017, 186, 43-50. [CrossRef]

43. Bilal, M.; Nichol, J.E.; Chan, P.W. Validation and accuracy assessment of a simplified aerosol retrieval algorithm (sara) over Beijing under low and high aerosol loadings and dust storms. Remote Sens. Environ. 2014, 153, 50-60. [CrossRef]

44. Bilal, M.; Nichol, J.E.; Bleiweiss, M.P.; Dubois, D. A simplified high resolution MODIS aerosol retrieval algorithm (sara) for use over mixed surfaces. Remote Sens. Environ. 2013, 136, 135-145. [CrossRef]

45. Sun, L.; Wei, J.; Bilal, M.; Tian, X.; Jia, C.; Guo, Y.; Mi, X. Aerosol optical depth retrieval over bright areas using landsat 8 oli images. Remote Sens. 2016, 8, 23. [CrossRef]

46. Mateos, D.; Bilbao, J.; Kudish, A.I.; Parisi, A.V.; Carbajal, G.; di Sarra, A.; Román, R.; de Miguel, A. Validation of omi satellite erythemal daily dose retrievals using ground-based measurements from fourteen stations. Remote Sens. Environ. 2013, 128, 1-10. [CrossRef]

47. Bilal, M.; Nichol, J. Evaluation of the NDVI-based pixel selection criteria of the MODIS C6 dark target and deep blue combined aerosol product. IEEE J. Sel. Top. Appl. Earth Obs. Remote Sens. 2017, 10, 3448-3453. [CrossRef]

48. He, L.; Wang, L.; Lin, A.; Zhang, M.; Bilal, M.; Wei, J. Performance of the NPP-VIIRS and Aqua-MODIS aerosol optical depth products over the Yangtze River Basin. Remote Sens. 2018, 10, 117. [CrossRef]

49. Wei, J.; Sun, L.; Huang, B.; Bilal, M.; Zhang, Z.; Wang, L. Verification, improvement and application of aerosol optical depths in China part 1: Inter-comparison of NPP-VIIRS and Aqua-MODIS. Atmos. Environ. 2018, 175, 221-233. [CrossRef]

50. Sayer, A.M.; Hsu, N.C.; Bettenhausen, C.; Jeong, M.J.; Meister, G. Effect of MODIS terra radiometric calibration improvements on Collection 6 deep blue aerosol products: Validation and Terra/Aqua consistency. J. Geophys. Res. Atmos. 2015, 120, 12157-12174. [CrossRef]

51. Bilal, M.; Nichol, J.; Spak, S. A new approach for estimation of fine particulate concentrations using satellite aerosol optical depth and binning of meteorological variables. Aerosol Air Qual. Res. 2017, 11, 356-367. [CrossRef]

52. Zou, B.; Pu, Q.; Bilal, M.; Weng, Q.; Zhai, L.; Nichol, J.E. High-resolution satellite mapping of fine particulates based on geographically weighted regression. IEEE Geosci. Remote Sens. Lett. 2016, 13, 495-499. [CrossRef]

53. You, W.; Zang, Z.; Zhang, L.; Li, Y.; Wang, W. Estimating national-scale ground-level PM25 concentration in China using geographically weighted regression based on MODIS and MISR AOD. Environ. Sci. Pollut. Res. Int. 2016, 23, 8327-8338. [CrossRef] [PubMed]

54. Li, R.; Gong, J.; Chen, L.; Wang, Z. Estimating ground-level PM2.5 using fine-resolution satellite data in the megacity of Beijing, China. Aerosol Air Qual. Res. 2015, 15, 1347-1356. [CrossRef]

55. Ma, Z.; Hu, X.; Sayer, A.M.; Levy, R.; Zhang, Q.; Xue, Y.; Tong, S.; Bi, J.; Huang, L.; Liu, Y. Satellite-based spatiotemporal trends in PM2.5 concentrations: China, 2004-2013. Environ. Health Perspect. 2015, 124, 184-192. [CrossRef] [PubMed]

56. Geng, G.; Zhang, Q.; Marin, R.V.; Donkelaar, A.V.; Huo, H.; Che, H.; Lin, J.; He, K. Estimating long-term PM2.5 concentrations in China using satellite-based aerosol optical depth and a chemical transport model. Remote Sens. Environ. 2015, 166, 262-270. [CrossRef]

57. Guo, Y.; Feng, N.; Christopher, S.A.; Kang, P.; Zhan, F.B.; Hong, S. Satellite remote sensing of fine particulate matter $\left(\mathrm{PM}_{2.5}\right)$ air quality over Beijing using MODIS. Int. J. Remote Sens. 2014, 35, 6522-6544. [CrossRef]

58. Ma, Z.; Hu, X.; Huang, L.; Bi, J.; Liu, Y. Estimating ground-level PM2.5 in China using satellite remote sensing. Environ. Sci. Technol. 2014, 48, 7436-7444. [CrossRef] [PubMed]

59. Snider, G.; Weagle, C.L.; Martin, R.V.; van Donkelaar, A.; Conrad, K.; Cunningham, D.; Gordon, C.; Zwicker, M.; Akoshile, C.; Artaxo, P.; et al. Spartan: A global network to evaluate and enhance satellite-based estimates of ground-level particulate matter for global health applications. Atmos. Meas. Tech. Discuss 2014, 7, 7569-7611. [CrossRef]

60. Saunders, R.O.; Kahl, J.D.W.; Ghorai, J.K. Improved estimation of PM2.5 using lagrangian satellite-measured aerosol optical depth. Atmos. Environ. 2014, 91, 146-153. [CrossRef]

61. Toth, T.D.; Zhang, J.; Campbell, J.R.; Hyer, E.J.; Reid, J.S.; Shi, Y.; Westphal, D.L. Impact of data quality and surface-to-column representativeness on the $\mathrm{PM}_{2.5}$ /satellite AOD relationship for the contiguous United States. Atmos. Chem. Phys. 2014, 14, 6049-6062. [CrossRef] 
62. Fang, X.; Zou, B.; Liu, X.; Sternberg, T.; Zhai, L. Satellite-based ground PM2.5 estimation using timely structure adaptive modeling. Remote Sens. Environ. 2017, 186, 152-163. [CrossRef]

63. Zou, B.; Wang, M.; Wan, N.; Wilson, J.G.; Fang, X.; Tang, Y. Spatial modeling of PM2.5 concentrations with a multifactoral radial basis function neural network. Environ. Sci. Pollut. Res. Int. 2015, 22, 10395-10404. [CrossRef] [PubMed]

64. Zou, B.; Luo, Y.; Wan, N.; Zheng, Z.; Sternberg, T.; Liao, Y. Performance comparison of LUR and OK in PM2.5 concentration mapping: A multidimensional perspective. Sci. Rep. 2015, 5, 8698. [CrossRef] [PubMed]

65. Parker, J.A.; Kenyon, R.V.; Troxel, D.E. Comparison of interpolating methods for image resampling. IEEE Trans. Med. Imaging 1983, 2, 31-39. [CrossRef] [PubMed]

66. Lehmann, T.M.; Gonner, C.; Spitzer, K. Survey: Interpolation methods in medical image processing. IEEE Trans. Med. Imaging 1999, 18, 1049-1075. [CrossRef] [PubMed]

67. Remer, L.A.; Kleidman, R.G.; Levy, R.C.; Kaufman, Y.J.; Tanré, D.; Mattoo, S.; Martins, J.V.; Ichoku, C.; Koren, I.; Yu, H.; et al. Global aerosol climatology from the MODIS satellite sensors. J. Geophys. Res. 2008, 113, D14S07. [CrossRef]

68. Bilal, M.; Nichol, J.E.; Nazeer, M. Validation of Aqua-MODIS C051 and C006 operational aerosol products using AERONET measurements over Pakistan. IEEE J. Sel. Top. Appl. Earth Obs. Remote Sens. 2016, 9, 2074-2080. [CrossRef]

69. Ichoku, C.; Remer, L.A.; Kaufman, Y.J.; Levy, R.C.; Chu, D.A.; Tanré, D.; Holben, B.N. Modis observation of aerosols and estimation of aerosol radiative forcing over Southern Africa during SAFARI 2000. J. Geophys. Res. 2003, 108, 8499. [CrossRef]

(c) 2018 by the authors. Licensee MDPI, Basel, Switzerland. This article is an open access article distributed under the terms and conditions of the Creative Commons Attribution (CC BY) license (http://creativecommons.org/licenses/by/4.0/). 